\title{
Molecular characterization of an endophytic Phomopsis liquidambaris CBR-15 from Cryptolepis buchanani Roem. and impact of culture media on biosynthesis of antimicrobial metabolites
}

\author{
H. C. Yashavantha Rao $\cdot$ Parthasarathy Santosh • \\ Devaraju Rakshith $\cdot$ Sreedharamurthy Satish
}

Received: 29 October 2013/Accepted: 18 February 2014/Published online: 19 March 2014

(C) The Author(s) 2014. This article is published with open access at Springerlink.com

\begin{abstract}
An endophytic fungus Phomopsis liquidambaris CBR-15, was isolated from Cryptolepis buchanani Roem. (Asclepiadaceae) and identified by its characteristic culture morphology and molecular analysis of the ITS region of rDNA and intervening 5.8S rRNA gene. The impact of different culture media on biosynthesis of antimicrobial metabolites was tested by disc diffusion assay. Polyketide synthase gene (PKS) of the endophytic fungus was investigated using three pairs of degenerate primers LC1-LC2c, LC3-LC5c and KS3-KS4c by PCR. TLCbioautography method was employed to detect the antimicrobial metabolites. Antimicrobial metabolites fractionated with ethyl acetate extract showed significant antimicrobial activity against the test bacteria and fungi. Biosynthesis of antimicrobial metabolites was optimum as depicted by zone of inhibition from ethyl acetate extract cultured in potato dextrose broth. Strain CBR-15 was identified as Phomopsis liquidambaris and PKS genes of the fungus were amplified with LC3-LC5c and KS3-KS4c sets of degenerate primers. These findings suggest that
\end{abstract}

The sequence data of this fungus is deposited in GenBank under the accession no. KF032029.

Electronic supplementary material The online version of this article (doi:10.1007/s13205-014-0204-2) contains supplementary material, which is available to authorized users.

H. C. Yashavantha Rao $\cdot$ D. Rakshith $\cdot$ S. Satish $(\bowtie)$

Department of Studies in Microbiology, University of Mysore,

Manasagangotri, Mysore 570 006, Karnataka, India

e-mail: satish.micro@gmail.com

P. Santosh

Plant Biotechnology Division, Unit of Central Coffee Research Institute, Coffee Board, Manasagangotri, Mysore 570 006,

Karnataka, India endophytic $P$. liquidambaris CBR-15 harbor iterative type I fungal PKS gene domain which indicates the biosynthetic potential of endophytic fungi as producers of natural antimicrobial metabolites. The study also demonstrates the utilization and optimization of different culture media which best supports for the biosynthesis of the antimicrobial metabolites from $P$. liquidambaris.

Keywords Endophytic fungus - Phomopsis

liquidambaris · Cryptolepis buchanani $\cdot$ Polyketide

synthase gene $\cdot$ Antimicrobial metabolites

\section{Introduction}

Natural products have been the major potential sources of chemical diversity while driving pharmaceutical discovery over the past century (Mishra and Tiwari 2011). Despite the present focus on synthetic products, natural products serve as continuing source of novel bioactive metabolites, retaining an immense impact on modern medicine (Wang et al. 2012). Microbial endophytes are viewed as an outstanding and unexplored source of novel bioactive natural products because many of them occupy literally millions of unique biological niches growing in a variety of unusual environments (Verma et al. 2007). Endophytic fungi are known to be as potential resources for producing bioactive compounds (Aly et al. 2010). They have proven to be promising sources of new and biologically active metabolites which are of interest for specific medicinal or agrochemical applications (Strobel and Daisy 2003). Infrequently, endophytic fungi capable of producing their host plant compounds have been discovered (Eyberger et al. 2006; Kusari et al. 2008, 2009a, b; Kusari and Spiteller 2011; Shweta et al. 2010). Based on knowledge of the 
chemistry and biology of endophytic fungi, the isolation of natural products can give us a platform to replace the existing synthetic drugs that provide resistance to pathogens and contaminate safe environment (Gond et al. 2012).

Polyketides have a great commercial interest for drug discovery and account for medicinal sales exceeding \$20 billion per year (Cheng et al. 2009). They are large family of structurally diverse natural products found in plants, fungi and bacteria. The study of PKS gene in natural environments may provide important ecological insights, in addition to opportunities for antimicrobial drug development (Zhao et al. 2008). The production of antibiotics by filamentous fungi can be enhanced by genetic modification, mixed culture fermentation, immobilization of the cells, optimization of fermentation conditions or enzymes induction (Oyama and Kubota 1993; Ho et al. 2003). Even minor variations in the environment or nutrition have the potential to impact the quantity and diversity of fermentation products. As an initial step in media optimization, nutritional array could be applied to cognize the conditions in which they would be more apt to produce antibiotics or secondary metabolites, resulting in enriched biological activity (Bills et al. 2008).

Cryptolepis buchanani Roem. and Schult. belongs to the family Asclepiadaceae, a climbing tree which is widely used in folk medicine in Southeast Asia (Laupattarakasem et al. 2003). It also plays a great medicinal value in Ayurveda as anti-diarrheal, anti-inflammatory and blood purifier (Kaul et al. 2003). In view of this, C. buchanani was selected for the isolation of fungal endophytes.

Here, we report for the first time on incidence of endophytic fungus from $C$. buchanani Roem. which comprises KS domain of fungal PKS gene as indicators of bioactivity. The impact of different culture media on biosynthesis of antimicrobial metabolites from $P$. liquidambaris CBR-15 was evaluated. The endophytic fungus has been identified by molecular analysis of the ITS region of rDNA containing ITS1, ITS2 and the intervening 5.8S rRNA gene.

\section{Materials and methods}

Collection site and source of endophytic fungus

Mysore $\left(12.3^{\circ} \mathrm{N} 76.6^{\circ} \mathrm{E}\right.$, elevation $\left.754 \mathrm{~m}\right)$ is located in the Southern part of India which has an annual mean temperature of $30{ }^{\circ} \mathrm{C}$ with about $786 \mathrm{~mm}$ precipitation per annum. C. buchanani Roem. was selected for the present study from this region. The plant is located in the campus of Mysore University. Healthy asymptomatic leaf, bark and root samples were collected and brought to the laboratory in an icebox which was used to isolate endophytic fungus within $24 \mathrm{~h}$ of collection.
Isolation of endophytic fungus

Collected samples were washed thoroughly in running tap water followed by distilled water before processing. To eliminate the epiphytic microorganisms, all the samples were initially rinsed with $70 \%$ ethanol for $2 \mathrm{~min}$ and surface sterilized by sodium hypochlorite (4\%) for $5 \mathrm{~min}$ and again rinsed with $70 \%$ ethanol for $30 \mathrm{~s}$. The samples were rinsed two times in sterile double distilled water and allowed for surface drying in sterile conditions. The plant materials were cut into small segments ( $5 \mathrm{~mm}$ size) and placed on water agar plates (distilled water, $1.5 \%$ agar) amended with chloramphenicol (250 ppm) and incubated at $30{ }^{\circ} \mathrm{C}$ for $3-4$ days to few weeks till the growth initiated. The hyphal tips, that emerged from the plant tissues were picked and maintained on PDA plates for further studies (Wang et al. 2012). The endophytic fungus used in the present study is maintained in the Department of Studies in Microbiology, University of Mysore, India (Voucher number: MGMB/DCC/02/2012).

\section{Culture media}

Four different culture media were used: Potato dextrose broth (PDB), Malt extract broth (MEB), Yeast extract sucrose broth (YSB) and Mycological broth (MCB).

\section{Fermentation and extraction}

The endophytic fungus was cultured in 1-1 Erlenmeyer flasks containing $500 \mathrm{ml}$ of each different culture media for 3 weeks at $25^{\circ} \mathrm{C}$ under static conditions. The culture broth was then filtered to separate the culture filtrate and mycelium. Culture filtrate was blended thoroughly and centrifuged at 4,000 rpm for $5 \mathrm{~min}$. Liquid supernatant was extracted with an equal volume of ethyl acetate thrice separately and this was evaporated to dryness under reduced pressure at $45{ }^{\circ} \mathrm{C}$ using rotary flash evaporator (Buatong et al. 2011). All the experiments were conducted in triplicates.

\section{Test microorganisms}

Gram-positive bacteria Staphylococcus aureus (MTCC 7443), Bacillus subtilis (MTCC 121), Listeria monocytogenes (MTCC 839). Gram-negative bacteria Escherichia coli (MTCC 7410), Salmonella typhi (MTCC 733), Pseudomonas aeruginosa (MTCC 7903), Candida albicans (MTCC 183) and Fusarium verticillioides.

Antimicrobial susceptibility testing

The determination of antimicrobial susceptibility testing was carried out by disc diffusion assay. The sterile discs 
(5 mm) were impregnated with $20 \mu \mathrm{l}(100 \mu \mathrm{g} / \mathrm{disc})$ of ethyl acetate extracts obtained from different culture media. The discs impregnated with ethyl acetate extract were dried in laminar hood and placed on the surface of the media already seeded with test microorganisms in Petri plates. One control disc impregnated with only $20 \mu \mathrm{l}$ of ethyl acetate was also placed for each test organism with a positive control. The plates were incubated at $37 \pm 2{ }^{\circ} \mathrm{C}$ and room temperature (for test bacteria and fungi, respectively) and the diameter of the zone of inhibition was measured (Sadrati et al. 2013).

\section{Statistical analyses}

Statistical analysis of results was performed using IBM SPSS version 20 (2011). One-way ANOVA (analysis of variance) at value $p<0.001$ followed by Tukey's Post Hoc test with $p<0.05$ was used to determine the significant differences between the results obtained in each experiment.

\section{Molecular characterization of the strain CBR-15}

\section{Isolation of genomic DNA}

The endophytic fungus was cultured in potato dextrose broth for 7 days at $30{ }^{\circ} \mathrm{C}$ under shaking conditions and the resultant mycelium was harvested by vacuum filtration and stored at $-70{ }^{\circ} \mathrm{C}$. The chilled mycelia were ground with mortar and pestle under liquid nitrogen then transferred into an Eppendorf microcentrifuge tube with $1 \mathrm{ml}$ of prewarmed $\left(65^{\circ} \mathrm{C}\right) 2 \times \mathrm{CTAB}$ extraction buffer $(2 \% \mathrm{w} / \mathrm{v}$ CTAB, $100 \mathrm{mM}$ Tris-HCl, $1.4 \mathrm{M} \mathrm{NaCl}, 20 \mathrm{mM}$ EDTA, $1 \% \beta$-mercaptoethanol, $\mathrm{pH} 8.0$ ), and then incubated in a $65^{\circ} \mathrm{C}$ water bath for $60 \mathrm{~min}$ with occasional gentle swirling. After centrifugation, the aqueous phase of the mixture containing the total DNA was reextracted with an equal volume phenol:chloroform:isoamyl alcohol (25:24:1). The residual phenol was removed with chloroform:isoamyl alcohol $(24: 1)$ twice. DNA in the aqueous phase was precipitated by adding 2 volume ethanol and 0.1 volume $3 \mathrm{M} \mathrm{NaAc}\left(\mathrm{pH}\right.$ 5.2) and then incubated at $-20{ }^{\circ} \mathrm{C}$ overnight. The DNA pellet was washed with $70 \%$ ethanol twice, and suspended in $50 \mu \mathrm{l}$ of TE buffer $(10 \mathrm{mM}$ TrisHCl, 1 mM EDTA, pH 8.0) (Kim et al. 2010).

\section{PCR amplification of ITS region of $r D N A$}

The ITS regions of the fungus were amplified by ITS primers, ITS1 ( $5^{\prime}$ TCCGTAGGTGAACCTGCGG $\left.3^{\prime}\right)$ and ITS4 (5' TCCTCCGCTTATTGATATGC $3^{\prime}$ ) (White et al. 1990). The PCR amplification was carried out in $0.2 \mathrm{ml}$ PCR tubes, using Master cycler personal (Eppendorf). The PCR reaction mixture $(50 \mu \mathrm{l})$ contained $5 \mu \mathrm{l} 10 \times$ PCR buffer containing $15 \mathrm{mM} \mathrm{MgCl}_{2}, 5 \mu \mathrm{l} 2 \mathrm{mM}$ deoxynucleoside triphosphates mix (dNTPs mix), $2 \mu \mathrm{l}$ of each primer $(5 \mathrm{pmol} / \mu \mathrm{l}), 4 \mu \mathrm{l}$ template DNA, $2 \mu \mathrm{l}(1 \mathrm{U} / \mathrm{ml})$ Taq polymerase and deionised water $(30 \mu \mathrm{l})$. Thermal cycling conditions were as follows: initial denaturation $\left(4 \mathrm{~min}\right.$ at $95{ }^{\circ} \mathrm{C}$ ), followed by 30 cycles of denaturation $\left(94{ }^{\circ} \mathrm{C}\right.$ for $\left.50 \mathrm{~s}\right)$, annealing $\left(51^{\circ} \mathrm{C}\right.$ for $\left.1 \mathrm{~min}\right)$, and primer extension $\left(72{ }^{\circ} \mathrm{C}\right.$ for $\left.1 \mathrm{~min}\right)$, followed by final extension for $10 \mathrm{~min}$ at $72{ }^{\circ} \mathrm{C}$. Amplification products were electrophoretically resolved on $1.4 \%(\mathrm{w} / \mathrm{v})$ agarose gel containing ethidium bromide $(0.5 \mu \mathrm{g} / \mathrm{ml})$, using $1 \times$ TAE buffer at $70 \mathrm{~V}$ (Bhagat et al. 2012).

Amplification of ketosynthase domain of fungal PKS gene of strain Phomopsis iquidambaris CBR-15

Three pairs of degenerate primers, LC1 and LC2c, LC3 and LC5c (Bingle et al. 1999), KS3 and KS4c (Nicholson et al. 2001), which are ketosynthase (KS) domain specific primers were used to amplify the KS domain sequence of the PKS genes of P. liquidambaris by PCR (Nicholson et al. 2001). PCR reactions $(50 \mu \mathrm{l})$ contained approximately $4 \mu \mathrm{l}$ genomic DNA template, $5 \mu 10 \times$ PCR buffer, $4 \mu \mathrm{l} 2.5 \mathrm{mM}$ of each dNTP, $3 \mu \mathrm{l}$ of each primer, $1 \mu \mathrm{l}$ of $2 \mathrm{U} / \mu \mathrm{l} \mathrm{Taq}$ DNA polymerase and $30 \mu \mathrm{l}$ deionised water. The thermal cycling program was as follows: $5 \mathrm{~min}$ at $94{ }^{\circ} \mathrm{C} ; 34$ cycles of $1 \mathrm{~min}$ at $94{ }^{\circ} \mathrm{C}, 1.5 \mathrm{~min}$ at $55^{\circ} \mathrm{C}$, $3 \mathrm{~min}$ at $72{ }^{\circ} \mathrm{C}$ and $10 \mathrm{~min}$ at $72{ }^{\circ} \mathrm{C}$.

\section{TLC-bioautography assay}

The antimicrobial activity of ethyl acetate extract was investigated by thin layer chromatography (TLC) using the bioautographic agar overlay method (Valgas et al. 2007). $10 \mu \mathrm{l}$ of ethyl acetate extract cultured in each different media was spotted on precoated TLC silica gel plates (TLC, ALUGRAM ${ }^{\circledR}$ SIL G/UV ${ }_{254}$, Machereye-Nagel, Germany) in an optimized solvent system of chloroform and methanol (9:1). The developed TLC plates were observed under visible light and UV light at $254 \mathrm{~nm}$ and $365 \mathrm{~nm}$, respectively. The developed TLC plates were air dried and UV sterilized for $30 \mathrm{~min}$. The TLC plates were then encased in sterile Petri plates and overlaid with Brain heart infusion medium (for $S$. aureus), Mueller-Hinton medium (for E. coli) and Sabouraud dextrose medium (for C. albicans) containing $0.65 \%$ agar incorporated with $1 \mathrm{mg} \mathrm{ml}^{-1}$ 2,3,5-triphenyl tetrazolium chloride (SigmaAldrich) inoculated with $1 \%$ standardized microbial inocula. After $8 \mathrm{~h}$ of diffusion at $8{ }^{\circ} \mathrm{C}$, the plates were incubated for $24 \mathrm{~h}$ at $37^{\circ} \mathrm{C}$ for bacteria and for $48-72 \mathrm{~h}$ at $25^{\circ} \mathrm{C}$ for fungi, then for fungi the upper agar was sprayed with [3-(4,5 dimethylthiazol-2-yl)-2,5 diphenyltetrazolium bromide] (MTT) (Sigma-Aldrich) $5 \mathrm{mg} \mathrm{mL}-1$ which was

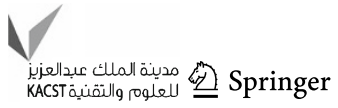


Fig. 1 a Colony morphology of P. liquidambaris CBR-15 on PDA and $\mathbf{b}$ microscopic features at $\times 40$ magnification showing alpha and beta conidia
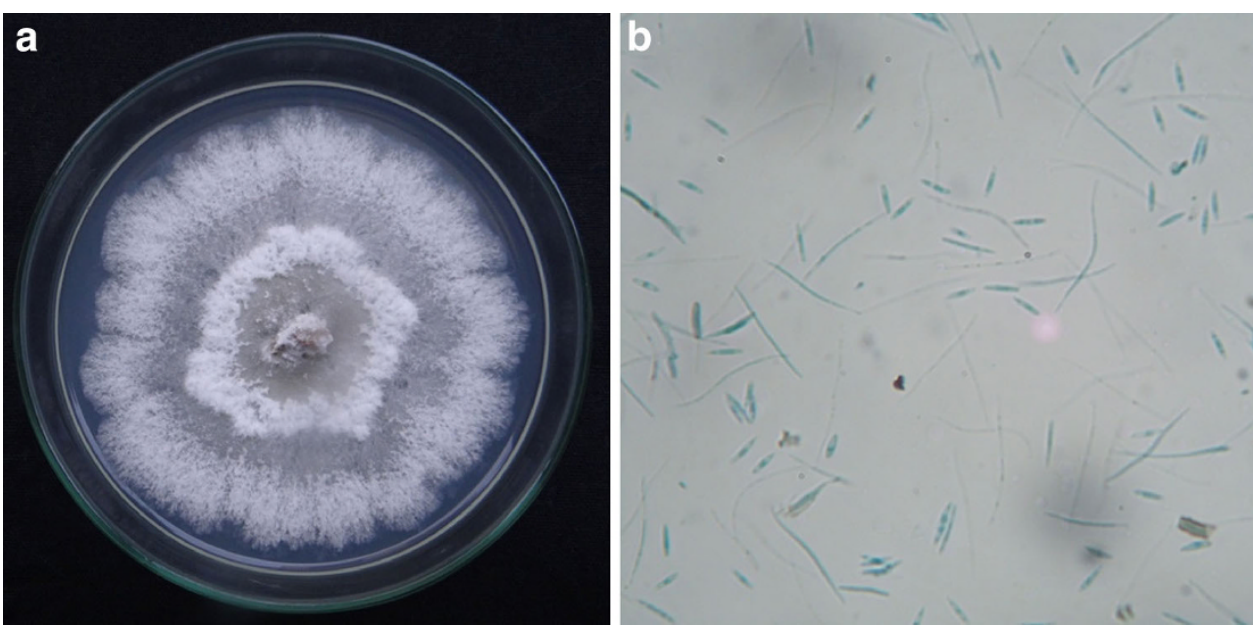

converted to a formazan dye by the test fungi. Inhibition zones were observed as clear spots against a red and purple background for bacteria and fungi, respectively. The areas of inhibition on the active spot were compared with the $R_{\mathrm{f}}$ value of the related spots on the reference TLC plate.

\section{Results and discussion}

Isolation of endophytic fungi and colony morphology endophytic fungal strain CBR-15

The endophytic fungus $P$. liquidambaris CBR-15 which is used in the present study was isolated from the leaf tissue of $C$. buchanani. Colony morphology on PDA, after 5 days at $25{ }^{\circ} \mathrm{C}$, initially cottony, white to olive gray later on turns to gray to light brown and a radiating growth pattern, margin regular. Conidiomata eustromatic, black, spherical to irregular on the upper regions; Conidiophores: short to elongated, aseptate to septate and branched, Conidia are of two types: (a) alpha conidia hyaline, straight, aseptate, forming white to yellowish cirrhi; (b) beta conidia hyaline, filiform, straight or curved, aseptae morphology characters observed, were closely related with the genus Phomopsis, belongs to class coelomycetes (Fig. 1).

Impact of culture media on antimicrobial activity

Antimicrobial activity was determined by disc diffusion assay to assess the relative concentration of the active metabolites in ethyl acetate extract cultured in different media. The strain CBR-15 cultured on different media composition exhibited significantly distinct impacts on their antimicrobial activity. Different media compositions induced comparable antimicrobial responses in an individual culture media; however, minor variations were also observed. Interestingly, the optimal response in respect to antimicrobial activity was observed in the ethyl acetate extract cultured in PDB when compared to rest of the media (Table 1). This may be due to the need for certain nutritional supplements, which may serve as precursors, for the biosynthesis of bioactive secondary metabolites in endophytic fungi (Tong et al. 2011). Gram-positive bacteria were more susceptible than Gram-negative bacteria. Ethyl acetate extract of $P$. liquidambaris cultured in PDB exhibited zone of inhibition $22.33 \pm 0.33$ and $21.00 \pm 0.00 \mathrm{~mm}$ for $S$. aureus and E. coli, respectively. Extract from YSB medium exhibited moderate antimicrobial response followed by PDB (Table 1).

During disc diffusion assay, antimicrobial activity of ethyl acetate extracts cultured in different media were analyzed. The utilization of different mycological media as nutritional supplements can impact on the production of bioactive secondary metabolites. Application of multiple fermentation conditions is the desirable method that could enhance the probability of successful discovery of bioactive metabolites from a given strain (Bills et al. 2008). One such way to trigger the production of secondary metabolites is to vary the medium composition. The principle behind this method, named as one strainmany compounds (OSMAC) approach, is to expose the microorganism to other cultivating conditions than the standards used in laboratories (Fuchser and Zeeck 1997; Schiewe and Zeeck 1999; Hofs et al. 2000; Bills et al. 2008). Media composition, temperature, $\mathrm{pH}$, culture vessel, aeration, cultivation time, light intensity can increase or reduce the production of the bioactive compounds by the strain (Bode et al. 2002; Siqueria et al. 2011). Yenn et al. (2012) reported anti-candidal activity of Phomopsis sp. ED2 cultured in yeast extract sucrose (YES) broth with aqueous extract of host plant. However, understanding of the exact mechanisms for the change in metabolic profile due to change in culture or fermentation conditions is usually not completely understood and 


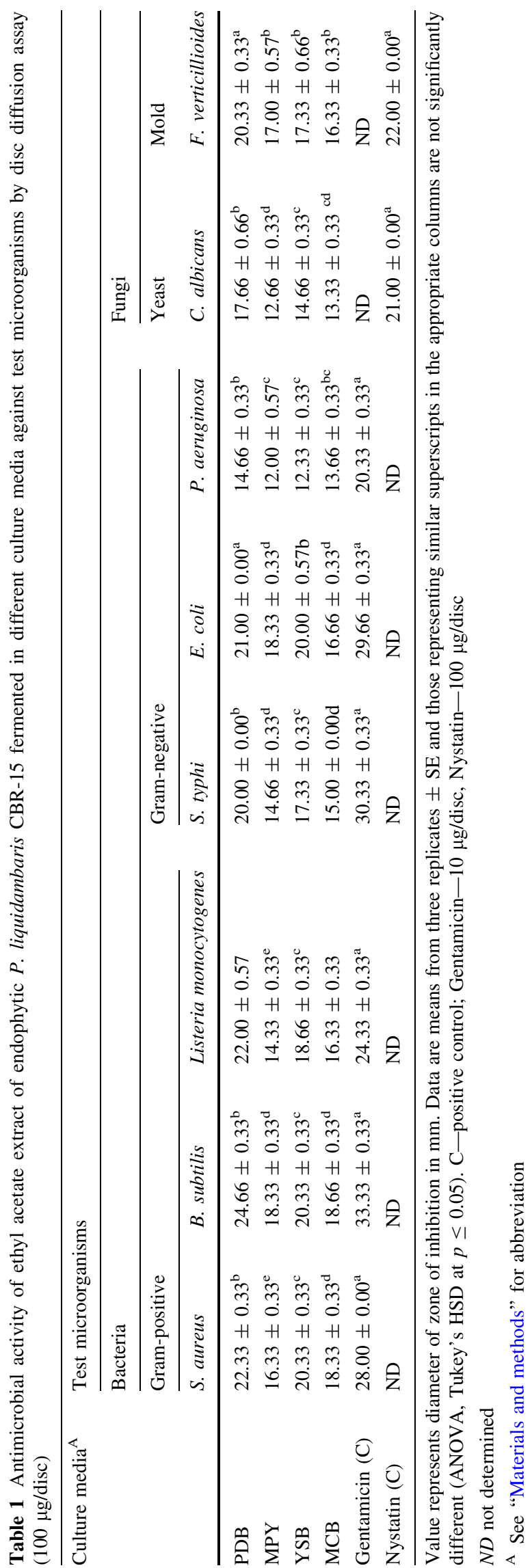

therefore difficult to predict (Bode et al. 2002). This work demonstrates that PDB serves as optimum culture media for the biosynthesis of antimicrobial metabolites which facilitates isolation and characterization of antimicrobial metabolites from P. liquidambaris (Fig. 2).

Molecular identification and amplification of ketosynthase domain of Phomopsis sp., PKS gene

The amplified ITS region of rDNA was sequenced and aligned with the ITS sequences of the different organisms retrieved from NCBI databases, using CLUSTAL W (Thompson et al. 1994). Dendrogram was generated using neighbor joining $(\mathrm{NJ})$ plot and the boot strapping was carried out using 1,000 replications. The acquisition of ITS1-5.8S-ITS2 sequence data and NJ plot showed that the isolate belongs to $P$. liquidambaris CJBB25-20, KC895530 (Fig. 3) which is also an endophytic fungus isolated from Saraca asoca (http://www.ncbi.nlm.gov/ nuccore/KC895530). The partial ITS sequence data of this fungus was deposited in GenBank, under accession no. KF032029.

Traditional bioprospecting of microbial endophytes recently initiated a genetic-based screening program of culturable endophytes to identify strains capable of producing bioactive secondary metabolites. Endophytic fungi have been genetically screened for the presence of PKS genes as indicators of bioactivity. In the present investigation, the genomic DNA of $P$. liquidambaris CBR-15 was amplified by LC3-LC5c and KS3-KS4c sets of degenerate primers (Fig. 4). Fungal PKSs are defined as iterative type I synthases and are classified into three groups based on the extent of reduction of the polyketide ring produced, namely non-reduced, partially reduced and highly reduced PKSs (Nicholson et al. 2001). To identify the presence of iterative type I PKS in P. liquidambaris CBR-15, LC1LC2c, LC3-LC5c and KS3-KS4c sets of degenerate primers were used which are specific for the particular types of the non-reduced, partially reduced and highly reduced KS domains of endophytic fungal PKS gene, respectively (Lin et al. 2010). From this study, P. liquidambaris CBR-15 might be capable of producing bioactive polyketide metabolites which are partially or highly reduced in nature due the amplification by LC3-LC5c and KS3-KS4c set of degenerate primers. The DNA of endophytic fungal strains isolated from Annona squamosa was investigated for PKS gene by KS domain specific primers. All three KS domains were present in the strains belonging to the Diaporthales (Lin et al. 2010). Investigation on PKS diversities in natural environment appears as an addition to opportunities for the development of microbial drugs which may provide important ecological insights (Zhao et al. 2008). 
Fig. 2 Antimicrobial activity of ethyl acetate extract of $P$. liquidambaris CBR-15 cultured in different media by disc diffusion assay against E. coli $(2 a$ and $2 b)$ and B. subtilis ( $2 c$ and $2 d$ ) where $+V E$ positive control, $-V E$ negative control and PDB,MPY, YSB, MCB are the different culture media (see "Materials and methods" for abbreviation) extract of Phomopsis liquidambari CBR-15
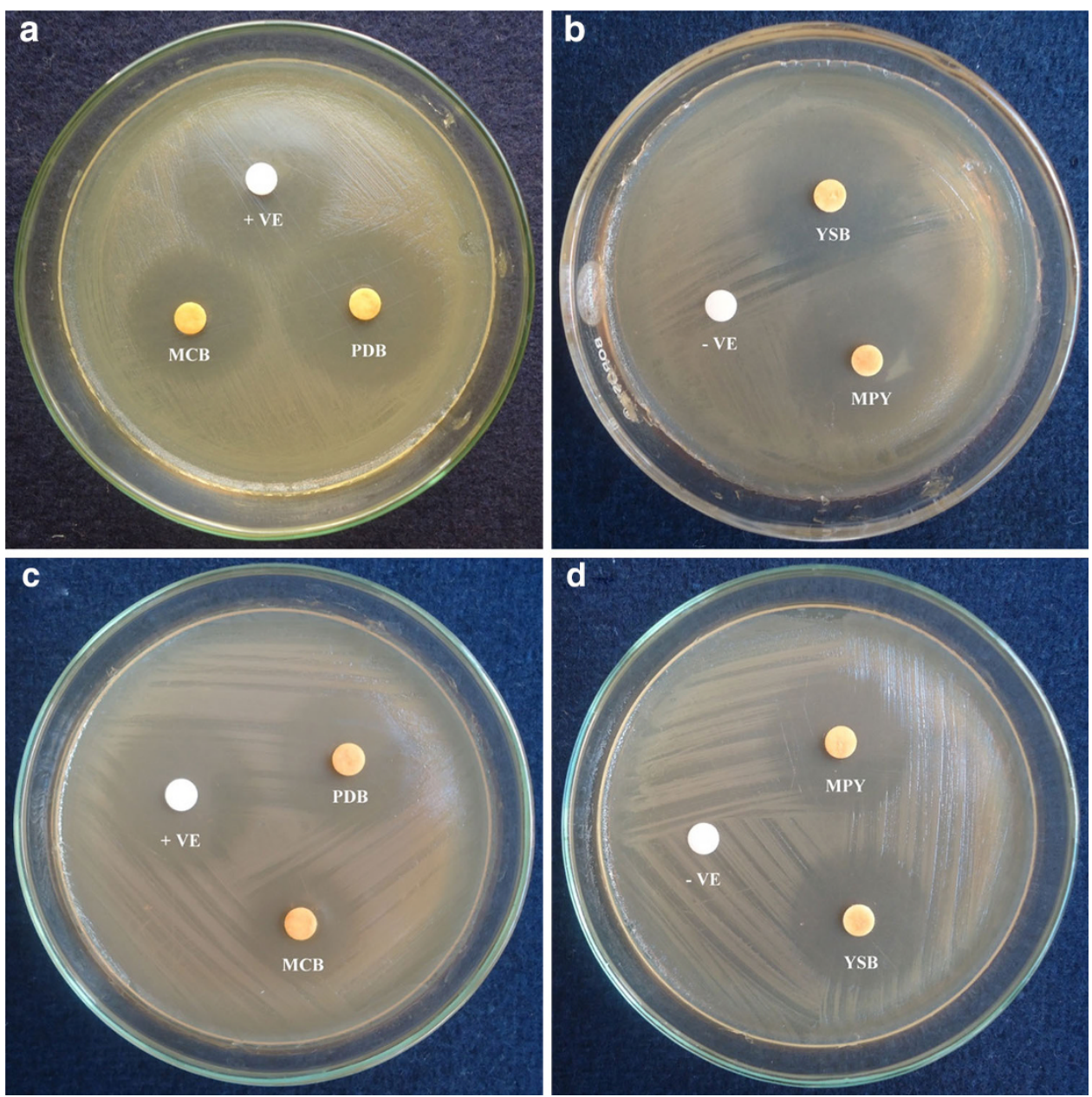

Fig. 3 ITS sequence-based Neighbor Joining tree of Phomopsis sp. isolates. A consensus NJ dendrogram with bootstrap values $(1,000$ replications) based on multiple sequence alignment. Scale bar indicated nucleotide substitutions per nucleotide position. * denotes the isolate obtained in the present study (accession no. KF032029)

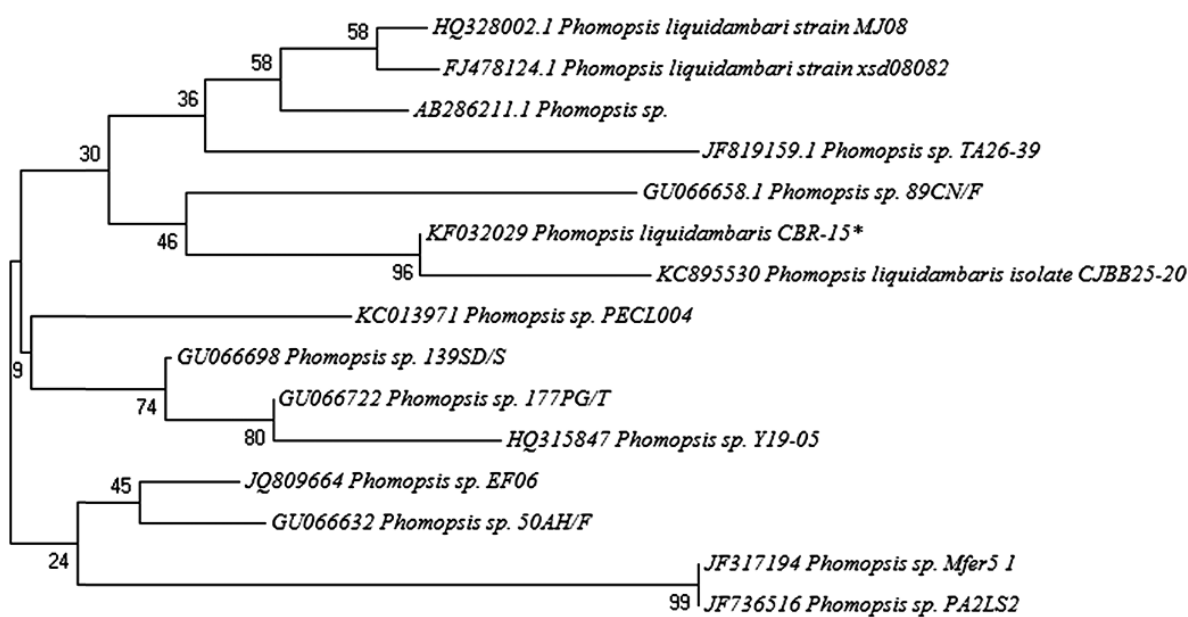

99 JF736516 Phomopsis sp. PA2LS2

\section{TLC-bioautography}

Metabolite profiling of ethyl acetate extract inclined from PDB medium by TLC showed better resolution of metabolites compared to rest of the media. Two major spots were observed under UV light of 254 and $365 \mathrm{~nm}$, respectively. On TLC, no comparable good resolution of metabolites was observed other than cultured in PDB. This implies that the availability of nutrient supplements in PDB medium enhanced the production of bioactive metabolites of 


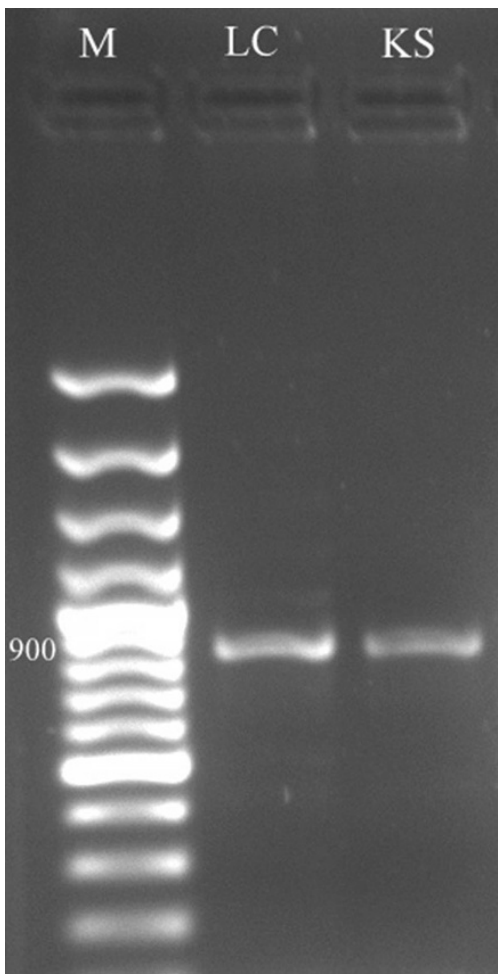

Fig. 4 PCR amplification of polyketide synthase gene (amplicon size about $900 \mathrm{bp}$ ) from $P$. liquidambaris CBR-15 by LC3-LC5c and KS3-KS4c pairs of degenerate primers. Lane: $M 100$ bp DNA ladder; $L C$ LC3-LC5c degenerate primers; $K S \quad \mathrm{KS} 3-\mathrm{KS} 4 \mathrm{c}$ degenerate primers

P. liquidambaris CBR-15. Certain nutrients act as environmental factors, quantitatively and qualitatively affecting the production of antimicrobial metabolites (Tabbene et al. 2009).

In the bioautography assay, the ethyl acetate extract inclined from PDB culture filtrate exhibited antimicrobial activity by producing zone of inhibition at $R_{\mathrm{f}}$ value 0.56 against S. aureus, E. coli and C. albicans (Fig. 5). A mild activity was also observed from YSB culture at similar $R_{\mathrm{f}}$ value against $S$. aureus and $C$. albicans, but it did not show any activity against $E$. coli. This indicates that the compound against $E$. coli can only be produced when the Phomopsis liquidambaris strain CBR-15 is cultured in PDB. A spot with a similar $R_{\mathrm{f}}$ was not observed in the ethyl acetate extract from MPY and MCB media. Yenn et al. (2012) reported anti-candidal activity of Phomopsis sp. ED2 cultured in yeast extract sucrose broth with addition of host extract, but in our study we reported the antimicrobial activity of Phomopsis sp. CBR-15 without host extract. The present study for the detection of antimicrobial compound by TLC is one of the simplest, economical and reproducible methods for drug discovery from natural products (Ahmed 2008; Hota 2010; Marston 2011; Patra et al. 2012). Further investigation is needed to characterize the antimicrobial metabolite.

\section{Conclusions}

Our finding implies that $P$. liquidambaris CBR-15, an endophytic fungus of $C$. buchanani, has antimicrobial properties and PDB is the best supporting media for the biosynthesis of antimicrobial metabolites. Bioactive natural compounds produced by endophytic fungi may provide new alternatives to address the problem of drug resistance development by human pathogens and multidrug resistance microorganisms. The genome mining strategy employed here might assist strain prioritization for the isolation and characterization of antimicrobial metabolites with polyketide biosynthetic origin. This work is the first report on incidence of endophytic fungus inhabiting $C$. buchanani Roem. which comprises KS domain of fungal PKS gene as indicators of bioactivity.
Fig. 5 TLC-bioautography agar over lay assay of ethyl acetate extract cultured in PDB against a $S$. aureus and $\mathbf{b} C$. albicans
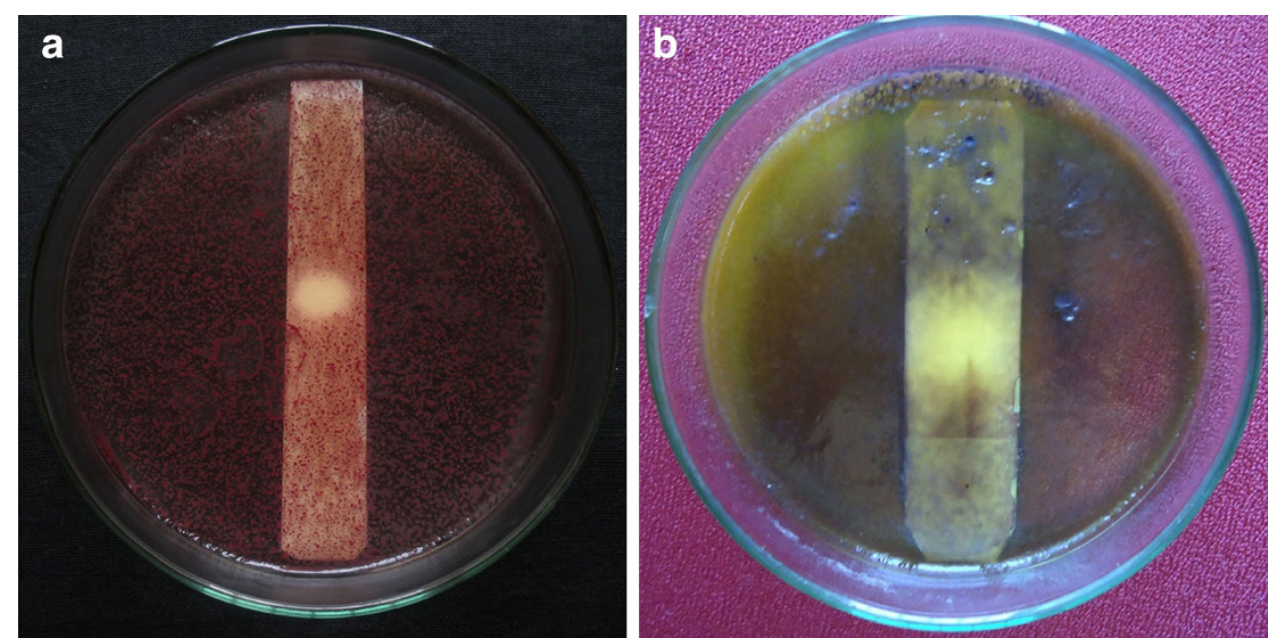
Acknowledgments This work was supported by University Grant Commission (UGC-Major Research Project) and Institution of Excellence, MHRD, New Delhi, India. Authors thank Department of Studies in Microbiology, University of Mysore for laboratory and instrumentation facilities.

Conflict of interest The authors declare that they have no conflict of interest.

Open Access This article is distributed under the terms of the Creative Commons Attribution License which permits any use, distribution, and reproduction in any medium, provided the original author(s) and the source are credited.

\section{References}

Ahmed MKK (2008) Introduction to isolation, identification and estimation of lead compounds from natural products. In: Hiremath SR (ed) Textbook of industrial pharmacy. Orient Longman Private Ltd, Chennai, pp 345-379

Aly AH, Debbab A, Kjer J, Proksch P (2010) Fungal endophytes from higher plants: a prolific source of phytochemicals and other bioactive natural products. Fungal Divers 41(1):1-16

Bhagat J, Kaur A, Sharma M, Saxena AK, Chadha BS (2012) Molecular and functional characterization of endophytic fungi from traditional medicinal plants. World J Microbiol Biotechnol 28:963-971

Bills GF, Platas G, Fillola A, Jimenez MR, Collado J, Vicente F et al (2008) Enhancement of antibiotic and secondary metabolite detection from filamentous fungi by growth on nutritional arrays. J Appl Microbiol 104:1644-1658

Bingle LE, Simpson TJ, Lazarus CM (1999) Ketosynthase domain probes identify two subclasses of fungal polyketide synthase genes. Fungal Genet Biol 26:209-223

Bode HB, Bethe B, Hofs R, Zeeck A (2002) Big effects from small changes: possible ways to explore nature's chemical diversity. Chembiochem 3:619-627

Buatong J, Phongpaichit S, Rukachaisirikul V, Sakayaroj J (2011) Antimicrobial activity of crude extracts from mangrove fungal endophytes. World J Microbiol Biotechnol 27:3005-3008

Cheng YQ, Coughlin LM, Lim SK, Shen B (2009) Type I polyketide synthases that require discrete acyltransferases. Methods Enzymol 459:165-186

Eyberger AL, Dondapati R, Porter JR (2006) Endophyte fungal isolates from Podophyllum peltatum produce podophyllotoxin. J Nat Prod 69:1121-1124

Fuchser J, Zeeck A (1997) Aspinolides and aspinonene/aspyrone cometabolites, new pentaketides produced by Aspergillus ochraceus. Liebigs Ann Recl 1997(1):87-95

Gond SK, Mishra A, Sharma VK, Verma SK, Kumar J, Kharwar RN et al (2012) Diversity and antimicrobial activity of endophytic fungi isolated from Nyctanthes arbortristis, a well-known medicinal plant of India. Mycoscience 53:113-121

Ho WH, To PC, Hyde KD (2003) Induction of antibiotic production of freshwater fungi using mix-culture fermentation. Fungal Divers 12:45-51

Hofs R, Walker M, Zeeck A (2000) Hexacyclinic acid, a polyketide from Streptomyces with a novel carbon skeleton. Angew Chem Int Ed 39:3259-3261

Hota D (2010) Evalution of plant extracts. In: Bioactive medicinal plants. Gene-Tech Books, New Delhi, pp 86-87
Kaul A, Bani S, Zutshi U, Suri KA, Satti NK, Suri OP (2003) Immunopotentiating properties of Cryptolepis buchanani root extract. Phytother Res 17:1140-1144

Kim JS, Seo SG, Jun KB, Kim JW, Kim SH (2010) Simple and reliable DNA extraction method for the dark pigmented fungus, Cercospora sojina. Plant Pathol J 26(3):289-292

Kusari S, Spiteller M (2011) Are we ready for industrial production of bioactive plant secondary metabolites utilizing endophytes? Nat Prod Rep 28:1203-1207

Kusari S, Lamshöft M, Zühlke S, Spiteller M (2008) An endophytic fungus from Hypericum perforatum that produces hypericin. J Nat Prod 71:159-162

Kusari S, Lamshöft M, Spiteller M (2009a) Aspergillus fumigatus Fresenius, an endophytic fungus from Juniperus communis L. Horstmann as a novel source of the anticancer pro-drug deoxypodophyllotoxin. J Appl Microbiol 107:1019-1030

Kusari S, Zühlke S, Spiteller M (2009b) An endophytic fungus from Camptotheca acuminate that produces camptothecin and analogues. J Nat Prod 72:2-7

Laupattarakasem P, Houghton PJ, Hoult JR, Itharat A (2003) An evaluation of the activity related to inflammation of four plants used in Thailand to treat arthritis. J Ethnopharmacol 85:207-215

Lin X, Jian Y, Zhong J, Zheng H, Su WJ, Qian XM et al (2010) Endophytes from the pharmaceutical plant, Annona squamosa: isolation, bioactivity, identification and diversity of its polyketide synthase gene. Fungal Divers 41:41-51

Marston A (2011) Thin-layer chromatography with biological detection in phytochemistry. Planar Chromatogr 13:2676-2683

Mishra BB, Tiwari VK (2011) Natural products: an evolving role in future drug discovery. Eur J Med Chem 46:4769-4807

Nicholson TP, Rudd BA, Dawson M, Lazarus CM, Simpson TJ, Cox RJ (2001) Design and utility of oligo nucleotide gene probes for fungal polyketide synthases. Chem Biol 8:157-178

Oyama M, Kubota K (1993) Induction of antibiotic production by protease in Bacillus brevis (ATCC8185). J Biochem 113:637-641

Patra JK, Gouda S, Sahoo SK, Thatoi HN (2012) Chromatography separation, ${ }^{1} \mathrm{H}$ NMR analysis and bioautography screening of methanol extract of Excoecaria agallocha L. from Bhitarkanika, Orissa, India. Asian Pac. J. Trop. Biomed 2(1):S50-S56

Sadrati N, Daoud H, Zerroug A, Dahamna S, Bouharati S (2013) Screening of antimicrobial and antioxidant secondary metabolites from endophytic fungi isolated from wheat (Triticum durum). J Plant Prot Res 53(2):128-136

Schiewe HJ, Zeeck A (1999) Cineromycins, $\gamma$-Butyrolactones and ansamycins by analysis of the secondary metabolite pattern created by a single strain Streptomyces. J Antibiot 52:635-642

Shweta S, Zühlke S, Ramesha BT, Priti V, Kumar PM, Ravikanth G, Spiteller M, Vasudeva R, Shaanker RU (2010) Endophytic fungal strains of Fusarium solani, from Apodytes dimidiata E. Mey. ex Arn (Icacinaceae) produce camptothecin, 10-hydroxycamptothecin and 9-methoxycamptothecin. Phytochemistry 71:117-122

Siqueria VMD, Conti R, Araujo JMD, Motta CMS (2011) Endophytic fungi from the medicinal plant Lippia sidoides Cham. and their antimicrobial activity. Symbiosis 53(2):89-95

Strobel G, Daisy B (2003) Bioprospecting for microbial endophytes and their natural products. Microbiol Mol Biol R 67(4):491-502

Tabbene O, Slimene IB, Djebali K, Mangoni ML, Urdaci MC, Limam F (2009) Optimization of medium composition for the production of antimicrobial activity by Bacillus subtilis B38. Biotechnol Prog 25(5):1267-1274

Thompson JD, Higgins DG, Gibson TJ (1994) CLUSTAL W: improving the sensitivity of progressive multiple sequence alignment through sequence weighting, position-specific gap 
penalties and weight matrix choice. Nucleic Acids Res 11(22):4673-4680

Tong WY, Darah I, Latiffah Z (2011) Antimicrobial activities of endophytic fungal isolates from medicinal herb Orthosiphon stamineus Benth. J Med Plants Res 5:831-836

Valgas C, Souza SM, Smania EFA, Smania AJ (2007) Screening methods to determine antibacterial activity of natural products. Braz J Microbiol 38:369-380

Verma VC, Gond SK, Kumar A, Kharwar RN, Strobel GA (2007) Endophytic mycoflora of bark, leaf, and stem tissues of Azadirachta indica A. Juss. (neem) from Varanasi (India). Microb Ecol 54:119-125

Wang LW, Xu G, Wang JY, Su ZZ, Lin FC, Zhang CL et al (2012) Bioactive metabolites from Phoma species, an endophytic fungus from the Chinese medicinal plant Arisaema erubescens. Appl Microbiol Biotechnol 93:1231-1239

White TJ, Bruns T, Lee S, Taylor JW (1990) PCR Protocols: A Guide to Methods and Applications Amplification and direct sequencing of fungal genes for phylogenetics. In: Innis M, Gelfand DH, Sninsky JJ, White TJ (eds) Academic Press, San Diego, pp 315-322

Yenn TW, Lee CC, Ibrahimand D, Zakaria L (2012) Enhancement of anti-candidal activity of endophytic fungus Phomopsis sp. ED2, isolated from Orthosiphon stamineus Benth, by incorporation of host plant extract in culture medium. J Microbiol 50:581-585

Zhao J, Yang N, Zeng R (2008) Phylogenetic analysis of type I polyketide synthase and non-ribosomal peptide synthetase genes in Antarctic sediment. Extremophiles 12:97-105 